\title{
Exploration of Organizational Commitment and Job Satisfaction of Faculty Members in Private Higher Education
}

\author{
Sabah M. Al-Najjar ${ }^{1} \&$ Maha K. Jawad ${ }^{2}$ \\ ${ }^{1}$ Professor, Alturath University College, Baghdad, Iraq \\ ${ }^{2}$ Assistant Professor, College of Administration and Economics, University of Baghdad, Iraq, \\ Correspondence: Sabah M. Al-Najjar, Professor, Alturath University College, Baghdad, Iraq. Tel: 964-790-160-0723. \\ E-mail: sabahalnajjar65@gmail.com
}

Received: January 21, 2020

Accepted: February 28, 2020

Online Published: March 4, 2020

doi:10.5430/bmr.v9n1p9

URL: https://doi.org/10.5430/bmr.v9n1p9

\begin{abstract}
The principal objective of this research is to explore organizational commitment and its effect on job satisfaction styles in a sample of teaching staff working at Alturath University college within the Private Higher Education (PHE) at Baghdad, Iraq. The research sample included 37 faculty members working at different departments. The authors developed a questionnaire with (5-points) Likert scale, and used it as the main instrument to collect data from the sample studied. The questionnaire was subjected to a Cronbach alpha test to verify its internal validity. The statistical package SPSS v.10 was used to analyze and present the data obtained through the questionnaire. The data were also used to test the research hypothesis. According to the responses of the sample members, the statistical tests assisted the research hypothesis which states that there is a significant relationship and effect between organizational commitment and job satisfaction. In addition, the analysis revealed that there is a strong level of organizational commitment among the sample studied. The results obtained by this research can direct the administrations of the college in planning job loads, and in improving organizational commitment. Although this research is limited to one private colleges, but its results add a great value since it provide several lessons that private education can benefit from. This work could, also, be considered as an attempt to increase our knowledge about the educational system in general, and on the PHE in specific.
\end{abstract}

Keywords: affective commitment, continuous commitment, normative commitment, organizational commitment, job satisfaction, higher private education

\section{Introduction}

Organizational commitment requires from the organization to retain personnel with high commitment and satisfied with their jobs. This could be realized through the achievement of desirable behavior by individuals towards customers and the direction of the organization where they work. Higher private colleges and universities must strive to create loyalty and organizational commitment among faculty members to achieve job satisfaction for them, which contributes in reducing work turnover, reduces absences, increases productivity, and to satisfy customers who could be: the student himself, his parents, the society, or the job market. The importance of this topic has aroused the interest among researchers in the field of organizational management because of its association with many behavioral aspects in the organization. However, it is noticeable that the higher education sector in Iraq (public and private) did not get its share of this type of research, for example, the researchers noticed the lack of researches or studies to measure organizational commitment and job satisfaction in Iraqi colleges and universities. The importance of organizational commitment comes from its impact on the level of performance of faculty members and their association with the organization, the great level of organizational commitment and job satisfaction leads to the stability of faculty members and improves their performance. Based on this, the problem of the present research is defined in the desire of exploring the level of organizational commitment and its impact on job satisfaction. The research sample consisted of 37 teaching staff members. The researchers used the questionnaire to collect data from the study sample, used computer and statistical methods to display the analysis and the results of the questionnaire, and to test the hypotheses. The statistical tests and analysis assisted the research hypothesis. The researchers aligned a set of recommendations to increase organizational commitments among some faculty members. This could be achieved through increasing the level of attachment to the college or university, and the desire to develop it. This research structure contains seven parts: The Introduction, 
Literature Review, Theoretical Background, Job Satisfaction, Research Methodology, Data Presentation and Analysis, Conclusions and Recommendation.

\section{Literature Review}

The purpose of this part is to review some researches and studies from the literature that are related to this work. The review of such works had a significant impact on supporting and strengthening this study. Although most of the studies reviewed reflected the existence of a relationship between organizational commitment and job satisfaction, the existence of a relationship between organizational commitment and job satisfaction has not been yet explored within the PHE in Iraq.

Malik, Nawab \& Naeem (2010) study was directed to investigate the impact of faculty members' job satisfaction on the dimensions of organizational commitment in the public universities in Pakistan. Furthermore, the authors attempted to measure the extent to which faculty members are committed to the university and how much they are satisfied with their jobs. The study sample consisted of 650 faculty members, the questionnaire was used to collect primary data. Regression analysis was used to analyze the data and in obtaining data to test the research hypothesis. The study revealed that satisfaction with the job itself, quality of supervision, and the pay signified a positive impact on organizational commitment of faculty members among the sample studied. Lumley, Coetzee, Tladinyane \& Ferreira (2011) performed a study to explore the relationship between employee job satisfaction and organizational commitment. The authors applied a cross-sectional survey on a sample of 86 workers at some information technology companies in South Africa. Statistical tools such as correlation and stepwise regression analysis to exploit the relationships between the two variables studied. The analysis revealed new evidence that could be used to improve organizational ability to retain employees working in the information technology industry. Pandy \& Khare (2012) attempted to identify the impact of job satisfaction and organizational commitment (independent variable) on staff's loyalty (dependent variable) to the organization. The authors administered a 5-point (Likert) scale questionnaire to collect primary data from a sample of 200 employees which comprised of 100 employee from the industrial sector, and 100 employees from the service sector. Statistical tools such correlation analysis, Variance and Standard Deviation, $\mathrm{COV}$, and factor analysis were used to analyze the primary data and to test the research hypothesis. The study repoeted that there is a strong impact of job satisfaction and organizational commitment on employee loyalty. The study, also, signified a difference in loyalty between employees in the manufacturing sector vis-à-vis employees in the service sector. Nguyen, Mai \& Nguyen, (2014) mentioned that organizational commitment contributes to employee stability and enhances customer service which reflects on improved company performance. The study was conducted in a sample of 11 banks in Ho Chi Minh City, and the sample study included 201 employees. The study revealed the effect of a set of high performance practices on employees' organizational commitment. The study recommended that commitment-based organizations should manifest increased support for their employees. Ahmad, Javed, \& Hamad, (2014), performed a study to verify the impact of organizational commitment and employee performance (as independent variables) on employee satisfaction (as the dependent variable). The study was conducted in the banking industry, where 110 employees were selected from 10 banks. The questionnaire was the main instrument to collect primary data. Statistical tools such as ANOVA analysis, correlation analysis, regression analysis were used to analyze the primary data and to test the research hypothesis. The study revealed that there is a positive relationship between organizational commitment and employee satisfaction on one hand, on the other hand, the study revealed a positive relationship between employee performance and employee satisfaction. Albdour \& Altarawneh (2014) conducted a study for the purpose of exploring the relationship between employee engagement represented by job engagement and organizational engagement. Organizational Commitment represented by affective, continuance, and normative commitments. The study took place in the banking sector in Jordan. The authors used a convenience sampling, and the sample consisted of 336 frontline employees. The authors administered a questionnaire to collect the primary data. The analysis showed that front line employees who have high job engagement and organizational engagement have affective commitment and normative commitment, while high employees' job engagement affect employees' continuance commitment. According to the authors the results of their research should fill the gap in the research of employees' engagement and commitment and its impact on the overall performance of the organization. Inann \& Ozdilekb (2015) reported that organizational commitment and job satisfaction of workers have a direct impact on the overall success of organizations. In addition, increasing the job satisfaction of employees can result in increased organizational commitment of employees. In this research, the authors attempted to verify the relationship between organizational commitment and job satisfaction among employees in the academic sector of nine private universities in Ankara, Turkey. An on-line self-report questionnaire revealed that the sample's demographics, affective commitment and normative commitment had a positive effect on job satisfaction, while continuance commitment had negative impact on job satisfaction level of employees in the private universities that were surveyed in this study. In his study, 
Pham (2016) attempted to verify the existence of a relationship between job satisfaction and organizational commitment within the telecommuting environment. The author claims that the relationship between job satisfaction and organizational commitment was not investigated before inside the telecommunication environment. The authors emphasized that understanding the work environment helps the telecommunication industry in improving the employee's job satisfaction. The findings of the study provided some insights into the role of a mediator which impacts on job satisfaction and affective commitment. The study recommended future studies on affective commitment for offshore employees in the telecommunication industry in Vietnam. Manap (2017) claims that organizational commitment and job satisfaction have gained significant importance to organizations. The author presented a theoretical study in which he highlighted that organizations are more and more concerned with attaining highlyqualified employees who have long term commitment to their organizations. The author presented the concepts of job satisfaction and its theories such as that of Maslow's Hierarchy of needs, Herzberg's Two-Factor Theory, and the Equity Theory. In addition the author reviewed the concept of organizational commitment and has presented its models, such as that of O'Reilly \& Chatman's Models, and the Three Component Model of Commitment. The author concluded that organizations should consider the interdependencies of job satisfaction and organizational commitment to integrate their employees within the company. Batugall (2019) conducted a study to investigate the organizational culture, organizational commitment and job satisfaction among a sample of faculty staff at St. Paul University System (SPUS). A questionnaire was administered to gather data, and statistical tools were used to analyze the primary data collected. The study revealed that there is a significant positive relationship between job satisfaction and organizational commitment. The author claims that the finding of this research could be used as a basis to improve organizational commitment and improve the ways of enhancing the level of job satisfaction among faculty members at SPUS. Lizote, Verdinelli \& Nascilmento, (2019) performed a study to verify the relationship between organizational commitment and job satisfaction among civil servants of city halls. The authors followed Meyer's and Allen's theoretical approach of organizational commitment. The statistical analysis conducted in this study revealed that civil servants of city hall express satisfaction when they are affectively committed and less satisfaction when their commitment is only expressed to comply with organizational standards. The review of the previous works helped the authors in conceptualizing and in forming this study, and has guided the authors in developing the preposition that organizational commitment is positively related to job satisfaction.

\section{Theoretical Background}

\subsection{Organizational Commitment Defined}

An early definition of organizational commitment was provided by Porter, Steers, Mowday and Boulian (1974) in which they conceptualized organizational commitment as "the strength of an individual's involvement in a particular organization". Meyer and Allen (1997) viewed organizational commitment from a behavioral side. They state that organizational commitment is "the psychological connection that employees have with their organization, characterized by a strong identification with the organization". Pandy \& Khare (2012) defined organizational commitment as the force that identifies the individual with his organization based on the belief and the absolute acceptance of the organization's objectives and values, the readiness of the individual to exert exceptional efforts to benefit his organization, and his willingness to continue his commitment to the organization.

\subsection{Types of Organization Commitment}

Based on the studies of Allen \& Meyer (1991), Backhshi et al. (2009), Kaur et al. (2010), Kabir and Parvin (2011),Yelmez et al., (2014), Manap (2017), Emhan, Arslan, Yasar, \& Cocuk, (2018), Nacpil \& Lacap (2018) and Batugal (2019), three types of organizational commitment are cited in the literature:

\subsubsection{Affective Commitment}

Refers to the emotional and positive attachment of the individual to his organization. Affective commitment is defined as the positive feelings that identifies and binds the individual to his organization based on the idea that the individual's objectives corresponds to that of the organization's objectives.

\subsubsection{Continuance Commitment}

The continuance commitment comes from the willingness of the individual to stay with the organization because he understands that leaving the organization will cost what he has invested in terms of time and friendships. In other words the individual is committed to his organization because he believes that leaving the organization shall result in many economic costs. Continuous commitment involves two dimensions: social sacrifice and lack of alternatives perceived. Thus, many employees are not ready to sacrifice these benefits. 


\subsubsection{Normative Commitment}

It deals with the feelings of the individual working for the organization. This feeling may exist in the individual even before he joins the organization through the individual's social relations and the principles and values he carries. In addition, Normative Commitment may develop after the individual joins the organization which comes from the willingness to be loyal to the organization and to work hard for it.

The organizational commitment is significant to the organization and researchers for several reasons: it could be used as a predictor of future behavioral aspects such as employee productivity, turnover, and absences, it could be used to identify individuals who need to increase their commitment to the organization, and it is an interesting domain which attracted humanitarians to study and observe it continuously.

\section{Job Satisfaction}

Govender and Grobler (2017) defined job satisfaction as an attitude resulting from the correspondence between the individual's abilities and the requirements of the job and the dispositional perspectives. Elsewhere, job satisfaction is defined as the positive feeling which is a result of the individual's appraisal to the characteristics of his or her job. It is, also, related to the individual's productivity, turnover, job accidents, job attitudes, absenteeism, and the willingness of individuals to participate in the activities of the organization.

\subsection{Factors Affecting Job Satisfaction}

According to Kathawala et al., (1990), Judge, Bono \&Lock (2000), Saari \& Judge (2004), Makerjee \& Malhorta (2004), Spector (2008), Pham (2016), and Lizote, Verdinelli \& Nascilmento, (2019) several factors have been identified to have an effect on job satisfaction, which are:-

\subsubsection{Job Nature}

Job nature refers to those jobs that offer the individual the possibility to accomplish his or her personal ambitions and interests. Researchers found that job variety, also, contributes much to job satisfaction.

\subsubsection{The Wage or Salary}

The wage or the salary refers to the amount of money the individual receives for the work he or she does for the organization where he works. Naturally, the amount received helps the individual to fulfill his or her needs such as travelling, health care, investment, and recreation.

\subsubsection{Co-workers}

The individual's satisfaction or dissatisfaction with his job may be the result of his or her coworkers. Many individuals seek respect and attention from their coworkers. Work environment that is aggressive and unstable, is likely to create tensions and conflicts among workers, which reduces job satisfaction. In this case management should interfere to solve problems and to reduce tensions.

\subsubsection{Relation with Superiors}

Good managers should understand that their subordinates look for attention, appreciating of their efforts, and rewards. On the other side, individuals seek to see the manager's door open to discuss the problems that prevent them from doing their jobs effectively and efficiently.

\subsubsection{Job Environment}

The Hawthorne Research Institute conducted a very famous study to identify the impact of temperature, humidity, noise, lightness, cleanliness, job setting, and diseases resulting from the job environment. The study revealed that the quality of the job environment has a direct effect on employee turnover, absenteeism, productivity, and job satisfaction. Several attempts were made, in the past, to measure job satisfaction. Spector (1997) identified six tools that could be used to measure job satisfaction as depicted in Figure 1. 


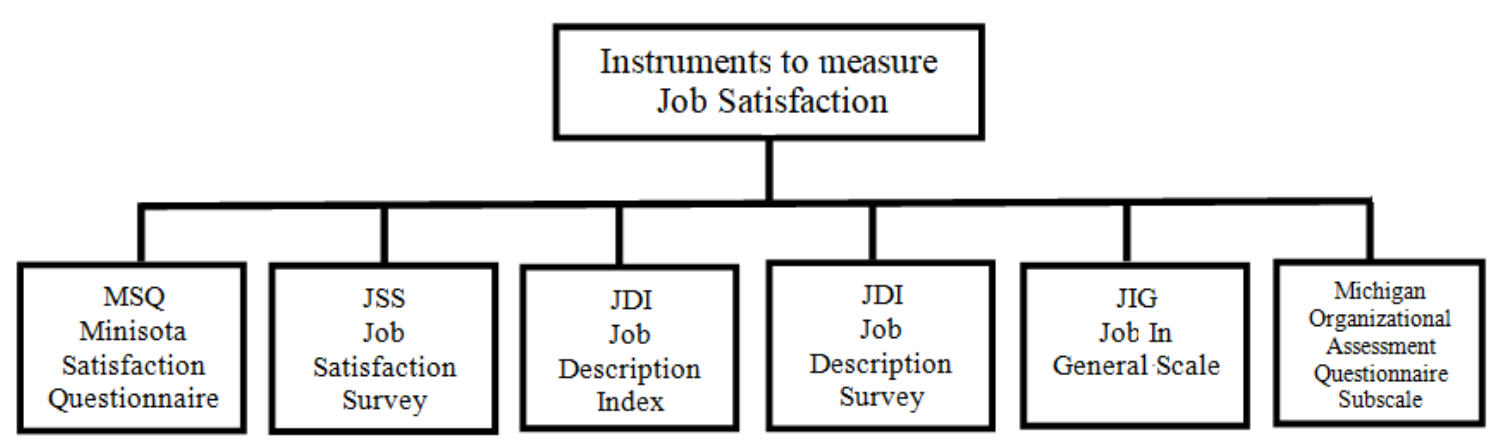

Source: Spector, 1997.

Figure 1. Job Satisfaction Measuring Instruments

\section{Research Methodology}

\subsection{Research Problem}

Our review of literature reveled an interest among researchers to explore the level of organizational commitment and job satisfaction among employees in different organizations. Since few studies attempted to explore this aspect, the authors decided to delve into this topic, which may be the first study in the PHE. Accordingly, the research problem is defined by the following questions:

1. To what degree do the organizational commitment variables affect job satisfaction among the faculty members studied?

2. To what degree does organizational commitment relate to job satisfaction according of the faculty members studied?

3. Is it possible to identify the kind of organizational commitment prevalent among the faculty members studied?

\subsection{Research Objectives}

This research attempts to achieve the following objectives:

1. Unveil the nature of the relationship between research variables: organizational commitment and job satisfaction.

2. Explore the nature of the impact of organizational commitment types on job satisfaction among faculty members studied.

3. Provide some suggestions that help in increasing the organization commitments of the faculty members studied.

4. Identification of the organizational commitment type(s) that is expressed by the sample studied.

5. Identify the factors that mostly influence job satisfaction.

6. Shed the light on the concepts of organizational commitment and job satisfaction.

7. Enrich the literature with new insights about organizational commitment and job satisfaction in PHE.

\subsection{Research Significance}

Organizational commitment and job satisfaction are rooted in the industrial sector. These concepts have gradually shifted to the service sectors. It has been shown through research that these two variables are of great importance to the survival of service organizations, because the employees provide the service directly to the customer. Therefore, workers who do not have high organizational commitment, and who are not satisfied with their jobs are not expected to please and satisfy customers. In the PHE sector, organizational commitment and job satisfaction have the greatest impact on the quality of service provided to students, for example, no college can achieve customer satisfaction (student, parents, field of work, etc.) before achieving the satisfaction of faculty members and deepen their organizational commitment. Hence, the importance of this research lies in increasing our understanding of higher education systems in general and the educational system in private higher education in particular which helps the 
deanship of colleges and scientific departments in taking the necessary measures to raise the levels of organizational commitment and job satisfaction among faculty members. We expect that the results of this study will help PHE administrators in the distribution of workload among staff and in identifying staff members whose job satisfaction and organizational commitment is low, and work to improve them.

\subsection{Research Participants}

The authors distributed 60 questionnaires to faculty members, 40 of them were returned, 3 of them were rejected; therefore the research sample consisted of 37 faculty members only. Table (1) provides the demographic distribution of the sample studied.

Table 1. The Demographic Distribution of the Sample Surveyed

\begin{tabular}{lllll}
\hline $\begin{array}{l}\text { Personal } \\
\text { Information }\end{array}$ & Characteristics & Frequency & Percentage & Total \\
\hline \multirow{2}{*}{ Gender } & Male & 32 & 86 & 37 \\
& Female & 5 & 14 & \\
\hline \multirow{3}{*}{ Title } & Assistant Ins. & 16 & 43 & 37 \\
& Instructor & 14 & 38 & \\
& Assistant Professor & 5 & 14 & 37 \\
\multirow{2}{*}{ Degree } & Professor & 2 & 5 & \\
& Higher Diploma & 0 & 59 & \\
\hline
\end{tabular}

\subsection{Research Model and Variables}

Based on the studies of Nacpil and Lacap (2018), Dabir \& Azarpir (2017), Govender \& Grobler (2017), Meyer \& Allen (1991), Allen and Meyer (1990) and McDonald \& Maclntyre (1997), the present research included two variables: Organizational Commitment as the independent variable, represented by a subset of variables: Affective Commitment, Continuous Commitment, and Normative Commitment. Job Satisfaction as the dependent variable, and is represented by a subset of variables: Job Nature, Salary or Wages, Relation with Superiors, Relation with Coworkers, and Job Environment. Figure 2 presents the research model. 


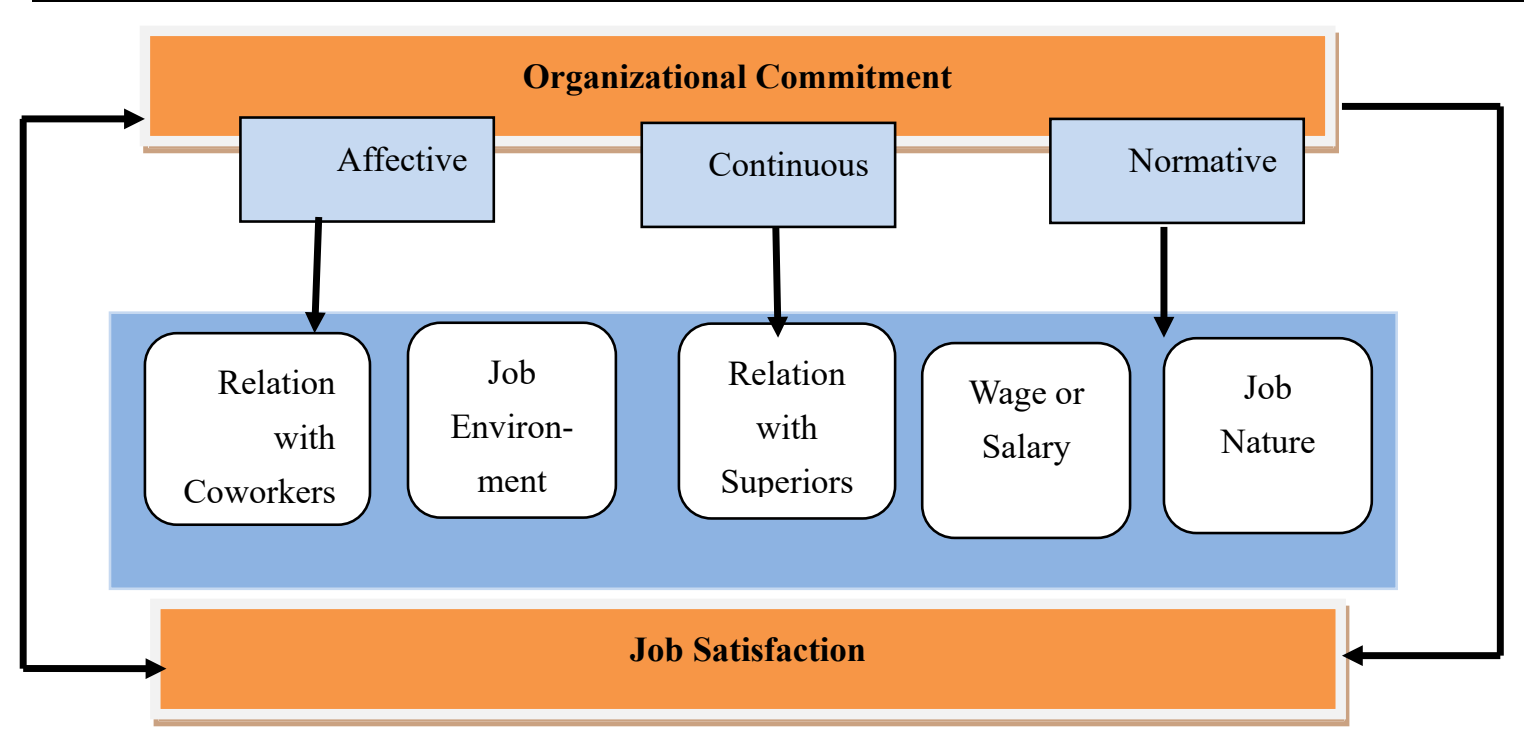

Figure 2. Research Model

\subsection{Materials and Methods}

The questionnaire was the main instrument used to collect the primary data from the sample studied, which included 37 staff members. The questionnaire was designed according to the above mentioned studies, and included twenty questions to obtain the sample's responses. Each question is based on a 5-point Likert scale. In order to confirm the internal validity and reliability of the questions, a Cronbach Alpha test has been used for this purpose. The computations show that the alpha coefficients were greater than 0.70 for all the questions. The authors used SPSS v. 10 to analyze the data obtained through the questionnaire. The results of the statistical analysis were presented and used in testing the research hypothesis. In addition to the questionnaire, the authors conducted personal interviews with faculty members to identify their type of organizational commitment.

\subsection{Research Hypothesis}

The present research attempts to test two major hypotheses:

$H_{l}$ : There is a significant relationship between organizational commitment and job satisfaction.

$\mathrm{H}_{2}$ : There is a significant effect of organizational commitment on job satisfaction.

\section{Data Presentation and Analysis}

\subsection{Analyzing the Responses Concerning the Organizational Commitment}

\subsubsection{Affective Commitment}

With reference to table (2), the mean of this construct was 4.37 which is higher than the default mean's value of 3 , with a standard deviation (std) of 0.13 . About $83 \%$ of the respondents agreed on the questions of this variable. Question no. 4 scored the highest among the questions of this variable with a mean of 4.59 and std of 0.63 which indicates a high consistency among respondents about this question. While question no. 3 scored the lowest with a mean of 4.30 and a std of 0.83 which indicates that the study sample does not highly see themselves as part of the PHE family. 
Table 2. Affective Commitment Responses Analysis

\begin{tabular}{|c|c|c|c|c|c|c|c|c|c|c|c|c|c|}
\hline \multirow[b]{2}{*}{ Q } & \multicolumn{2}{|c|}{$\begin{array}{l}\text { Strongly } \\
\text { agree }\end{array}$} & \multicolumn{2}{|c|}{ Agree } & \multicolumn{2}{|c|}{$\begin{array}{l}\text { Not } \\
\text { Sure }\end{array}$} & \multicolumn{2}{|c|}{ Disagree } & \multicolumn{2}{|c|}{ Strongly } & \multirow[t]{2}{*}{ Mean } & \multirow[t]{2}{*}{ STD } & \multirow[t]{2}{*}{$\mathrm{COV}$} \\
\hline & freq & $\%$ & Freq & $\%$ & freq & $\%$ & freq & $\%$ & freq & $\%$ & & & \\
\hline 1 & 22 & 0.59 & 8 & 0.22 & 5 & 0.14 & 2 & 0.05 & 0 & 0 & 4.35 & 0.91 & 0.208 \\
\hline 2 & 20 & 0.54 & 12 & 0.32 & 2 & 0.05 & 3 & 0.08 & 0 & 0 & 4.32 & 0.90 & 0.209 \\
\hline 3 & 18 & 0.49 & 14 & 0.38 & 3 & 0.08 & 2 & 0.05 & 0 & 0 & 4.30 & 0.83 & 0.194 \\
\hline 4 & 25 & 0.68 & 9 & 0.24 & 3 & 0.08 & 0 & 0.00 & 0 & 0 & 4.59 & 0.63 & 0.138 \\
\hline \multirow[t]{2}{*}{5} & 19 & 0.51 & 12 & 0.32 & 3 & 0.08 & 3 & 0.08 & 0 & 0 & 4.27 & 0.92 & 0.215 \\
\hline & & & & & & & & & & & 4.37 & 1.3 & 0.28 \\
\hline
\end{tabular}

\subsubsection{Continuance Commitment}

With reference to Table (3), the overall mean of this construct was 4.36 which is higher than the default mean's value of 3 , with a std of 0.14 . About $85 \%$ of the respondents agreed on this variable. Question no. 10 scored the highest with a mean of 4.54 and a std of 0.12 which is rather low, and indicates that the faculty members think that they might lose the financial benefits if they quit working at PHE. While question no. 8 scored the lowest with a mean of 4.16 and a std of 0.15 which is relatively low. Seventy Three percent agreed on this question, which highlights that more than $50 \%$ of the study sample believe the existence of job opportunities in case they quit working at the PHE.

Table 3. Continuance Commitment Responses Analysis

\begin{tabular}{|c|c|c|c|c|c|c|c|c|c|c|c|c|c|}
\hline \multirow[b]{3}{*}{ Q } & \multirow{2}{*}{\multicolumn{2}{|c|}{$\begin{array}{l}\text { Strongly } \\
\text { agree }\end{array}$}} & \multirow{2}{*}{\multicolumn{2}{|c|}{ Agree }} & \multirow{2}{*}{\multicolumn{2}{|c|}{$\begin{array}{l}\text { Not } \\
\text { Sure }\end{array}$}} & \multirow{2}{*}{\multicolumn{2}{|c|}{ Disagree }} & \multirow{2}{*}{\multicolumn{2}{|c|}{$\begin{array}{l}\text { Strongly } \\
\text { Disagree }\end{array}$}} & \multirow{3}{*}{ Mean } & \multirow{3}{*}{ STD } & \multirow{3}{*}{$\mathrm{COV}$} \\
\hline & & & & & & & & & & & & & \\
\hline & freq & $\%$ & Freq & $\%$ & freq & $\%$ & freq & $\%$ & freq & $\%$ & & & \\
\hline 6 & 18 & 0.49 & 13 & 0.35 & 5 & 0.14 & 1 & 0.03 & 0 & 0 & 4.30 & 0.80 & 0.186 \\
\hline 7 & 21 & 0.57 & 10 & 0.27 & 5 & 0.14 & 1 & 0.03 & 0 & 0 & 4.38 & 0.13 & 0.031 \\
\hline 8 & 17 & 0.46 & 10 & 0.27 & 9 & 0.24 & 1 & 0.03 & 0 & 0 & 4.16 & 0.15 & 0.035 \\
\hline 9 & 24 & 0.65 & 7 & 0.19 & 4 & 0.11 & 1 & 0.03 & 1 & 0.03 & 4.41 & 0.16 & 0.036 \\
\hline \multirow[t]{2}{*}{10} & 25 & 0.68 & 8 & 0.22 & 3 & 0.08 & 1 & 0.03 & 0 & 0 & 4.54 & 0.12 & 0.027 \\
\hline & & & & & & & & & & & 4.36 & 0.140 & 0.032 \\
\hline
\end{tabular}

\subsubsection{Normative Commitment}

Table (4) presents the analysis responses with respect to Normative Commitment. The overall mean of this construct was 4.43 which is higher than the default mean's value of 3 , with a std of 0.11 . About $90 \%$ of the respondents agreed on this variable which signifies the importance of it. Question no. 15 scored the highest with a mean of 4.54 and a std of 0.08 which is rather low, and indicates that the faculty members feel that they are morally committed to continue working at the PHE. While question no. 11 scored the lowest with a mean of 4.24 and a std of 0.16 which is relatively low. It could be said that the study sample believes that an individual should be loyal to the organization where he works. 
Table 4. Normative Commitment Responses Analysis

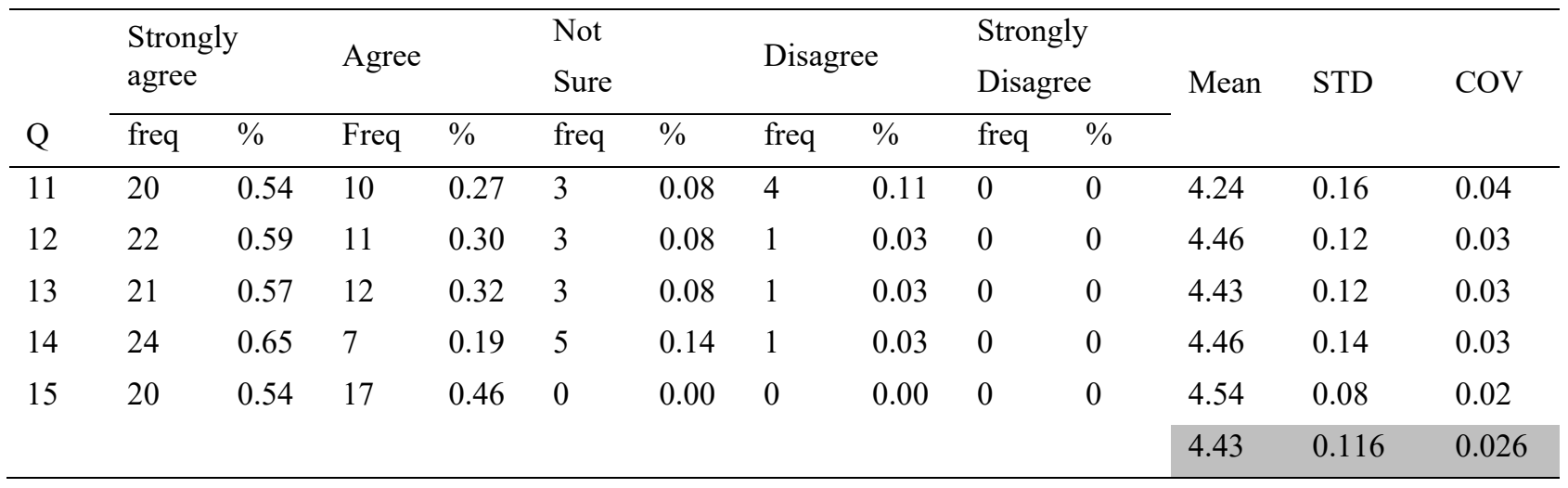

\subsection{Analyzing the Responses Concerning Job Satisfaction}

With reference to table (5), the overall mean of the dependent variable was 4.41 which is higher than the default's mean value of 3 , with a std of 0.063 . Eighty six percent of the respondents agreed on this variable. In other words the pay, the job nature, the relationship with superiors, relationships with co-workers, and the work environment constitute important factors that shape job satisfaction among the study sample. Question no. 5 which is concerned with the relationship with superiors scored the highest with a mean of 4.49 and a std of 0.14 . This means that the relationship with superiors is important in creating job satisfaction among faculty members at the PHE. The agreement percentage on this question was $89 \%$, the disagreement rate was $5 \%$, and $5 \%$ of the respondents were neutral about this question. While question 19, the job environment, scored the least with a mean of 4.35 and a std of 0.13 . Although job environment scored the least but its mean is still above the default's mean of 3 .

Table 5. Job Satisfaction Responses Analysis

\begin{tabular}{|c|c|c|c|c|c|c|c|c|c|c|c|c|c|}
\hline \multirow[t]{2}{*}{ Q } & \multicolumn{2}{|c|}{$\begin{array}{l}\text { Strongly } \\
\text { agree }\end{array}$} & \multicolumn{2}{|c|}{ Agree } & \multicolumn{2}{|c|}{$\begin{array}{l}\text { Not } \\
\text { Sure }\end{array}$} & \multicolumn{2}{|c|}{ Disagree } & \multicolumn{2}{|c|}{$\begin{array}{l}\text { Strongly } \\
\text { Disagree }\end{array}$} & \multirow[t]{2}{*}{ Mean } & \multirow[t]{2}{*}{ STD } & \multirow[t]{2}{*}{$\mathrm{COV}$} \\
\hline & freq & $\%$ & Freq & $\%$ & freq & $\%$ & freq & $\%$ & freq & $\%$ & & & \\
\hline 16 & 19 & 0.51 & 13 & 0.35 & 4 & 0.11 & 1 & 0.03 & 0 & 0 & 4.35 & 0.13 & 0.0298 \\
\hline 17 & 21 & 0.57 & 11 & 0.30 & 3 & 0.08 & 2 & 0.05 & 0 & 0 & 4.38 & 0.14 & 0.0319 \\
\hline 18 & 22 & 0.59 & 8 & 0.22 & 5 & 0.14 & 2 & 0.05 & 0 & 0 & 4.35 & 0.15 & 0.0344 \\
\hline 19 & 22 & 0.59 & 11 & 0.30 & 3 & 0.08 & 1 & 0.03 & 0 & 0 & 4.46 & 0.12 & 0.0269 \\
\hline \multirow[t]{2}{*}{20} & 24 & 0.65 & 9 & 0.24 & 2 & 0.05 & 2 & 0.05 & 0 & 0 & 4.49 & 0.14 & 0.0311 \\
\hline & & & & & & & & & & & 4.41 & 0.063 & 0.014 \\
\hline
\end{tabular}

\subsection{Analyzing the Correlation between Organizational Commitment and Job Satisfaction}

Table (6) presents the results of calculating the correlation coefficient between each independent variable and the dependent variable. It is clear from this table that there is a positive correlation between the independent variables and the dependent variable. The first variable ( Affective or Emotional Commitment) achieved a positive correlation coefficient of 0.30 , the correlation coefficient was significant at 0.05 (two-tale test). The value of the coefficient of determination for this variable was 0.09 . The coefficient of determination refers to the quality of the regression model.

The second variable (Continuous Commitment) achieved a correlation coefficient of 0.87 , which is greater than the correlation coefficient obtained by the first variable (Affective Commitment) and the value of this correlation coefficient was significant at 0.05 (two-tail test). The value of the coefficient of determination of this variable was 0.76 . The value of the correlation coefficient realized by this variable indicates that there is a strong positive relationship between Continuous Commitment and Job Satisfaction. 
Table 6. Results of Correlation Analysis

\begin{tabular}{|c|c|c|c|c|c|c|c|}
\hline \multirow[b]{2}{*}{$\begin{array}{l}\text { Independent } \\
\text { Variable }\end{array}$} & \multicolumn{7}{|c|}{ Dependent Variable (Job Satisfaction) } \\
\hline & $\begin{array}{l}\text { Correlation } \\
\text { Coefficient } \\
R\end{array}$ & $\begin{array}{l}\text { Coeff. } \\
\text { Of Deter. } \\
r^{2}\end{array}$ & $\begin{array}{l}t \\
c a l\end{array}$ & $\begin{array}{l}t \\
t a b\end{array}$ & s.l. & d.f. & $\begin{array}{l}\text { Test } \\
\text { Result }\end{array}$ \\
\hline Affective Commitment & 0.30 & 0.09 & 2.76 & 1.99 & 0.05 & 72 & Sig \\
\hline Continuance Commitment & 0.87 & 0.76 & 14.97 & 1.99 & 0.05 & 72 & Sig \\
\hline Normative Commitment & 0.72 & 0.52 & 8.80 & 1.99 & 0.05 & 72 & Sig \\
\hline
\end{tabular}

The third variable, the Normative Commitment, obtained a positive correlation coefficient of 0.72 , a strong correlation, i.e., the greater the value of the normative commitment, the greater the value of job satisfaction. The value of the coefficient of determination for this variable was 0.52 , which indicates the quality of the regression model for this variable.

Given that all tests of correlation coefficients are significant, this analysis fully supports the validity of the first main hypothesis, which states that "there is a significant correlation between the organizational commitment and job satisfaction in accordance with the responses of the sample studied".

\subsection{Analyzing the Effect of Organizational Commitment on Job Satisfaction}

Table (7) shows the simple regression analysis to measure the effect of the independent variable on the dependent variable. The analysis reveals that the normative commitment had the highest effect with $(\beta=+0.42)$. This means that a change of 1 in this variable will increase job satisfaction by 0.42 . With respect to affective commitment variable, the value of the coefficient $(\beta=+0.15)$ was positive, i.e. a change of 1 in this variable will increase the value of job satisfaction by 0.15 . Finally, the analysis showed that the effect coefficient value of the continuance commitment variable was $(\beta=+0.40)$ which is lower than the coefficient of influence of the previous variable. Since the statistical tests results were significant, the second hypothesis is accepted, which states that "there is a significant effect of organizational commitment on job satisfaction".

Table 7. Results of the Regression Analysis

\begin{tabular}{lllllllll}
\hline & \multicolumn{7}{c}{ Dependent Variable (Job Satisfaction) } & \\
\cline { 2 - 7 } Independent Variable & s.l. & d.f. & t tab & t cal & $\begin{array}{l}\text { Beta } \\
\beta\end{array}$ & & $\begin{array}{l}\text { Inter-cept } \\
\text { Test Result }\end{array}$ & \\
\hline Affective Commitment & 0.05 & 72 & 1.99 & 0.0463 & 0.15 & 3.25 & sig \\
Continuance Commitment & 0.05 & 72 & 1.99 & 0.0460 & 0.40 & 2.65 & sig \\
Normative Commitment & 0.05 & 72 & 1.99 & 0.0447 & 0.42 & 2.54 & sig \\
\hline
\end{tabular}

The authors went one step further by conducting interviews with the sample studied to identify each one's type of organizational commitment. The interviews revealed that 10,20, and 7 members feel they have affective, continuance, and normative commitment respectively. The majority of faculty members studied feel that they have continuance commitment which coincides, approximately, with the correlation analysis (Table 6) and regression analysis (Table 7).

\section{Conclusions and Recommendations}

The present study is intended to ascertain the effect and correlation between organizational commitment and job satisfaction among university staff members at the PHE in Iraq. From the statistical analysis conducted in this study, it could be concluded that the staff members studied were, in general, satisfied with their jobs at the university college, and meanwhile they are committed to it. The variables of the independent construct (affective, continuance, and normative commitments) demonstrated significant correlation and effect on the dependent construct, the job satisfaction. This suggests that staff members who exhibit organizational commitment also exhibit job satisfaction. Furthermore, the analysis reveals that as the organizational commitment increases, the level of job satisfaction goes up, too. This requires from the university administrators to pay much attention to these two variables. Therefore, it may be 
inferred that affective, continuance, and normative commitments could be used as predictors of job satisfaction. Furthermore, from the analysis of this study it could be concluded that organizational commitment may be developed gradually over time through the creation of an organizational culture that fosters values among staff members to produce high levels of job satisfaction. The analysis performed in this study indicates that satisfied staff members may bypass their job expectations and improve the learning environment which reflects on better campus and better student retention rates.

Before ending this work, it is worthwhile saying that deanships should take a bundle of measures to increase organizational commitment and job satisfaction such as: involving staff members in the process of program design so that they can demonstrate their skills and inventive abilities, maintaining and upgrading salaries to retain staff members, continuously improve the university's working conditions, encourage the studies that are related to explore the reasons leading to a decrease in organizational commitment, increase the cooperation between deanship and Academic Union representatives to solve staff's problems, allocating one hour per week to interview staff members to listen to their complaints and try to solve it, and assigning staff members to teach topics in their own specialty to allow them to demonstrate their abilities. Although this research is limited to Private Colleges, however, we recommend future researches to be conducted among faculty members in Public Universities in Iraq to verify whether the results coincide with the results of this research or not, and why?

\section{References}

Ahmad, N., Iqbal, N., Javed, K., \& Hamad, N. (2014). Impact of organizational commitment and employee performance on the employee satisfaction. International Journal of Learning, Teaching and Educational Research, 1(1), 84-92.

Albdour, A. A., \& Altarawneh, I. I. (2014). Employee engagement and organizational commitment: Evidence from Jordan. International journal of business, 19(2), 192.

Allen, N. J., \& Meyer, J. P. (1990). The measurement and antecedents of affective, continuance and normative commitment to the organization. Journal of occupational psychology, 63(1), 1-18. https://doi.org/10.1111/j.2044-8325.1990.tb00506.x

Bakhshi, A., Kumar, K., \& Rani, E. (2009). Organizational justice perceptions as predictor of job satisfaction and organization commitment. International journal of Business and Management, 4(9), 145-154. https://doi.org/10.5539/ijbm.v4n9p145

Batugal, M. L. C. (2019). Organizational Culture, Commitment and Job Satisfaction of Faculty in Private-Sectarian Higher Education Institutions (HEIs). World Journal of Education, 9(2), 123-135. https://doi.org/10.5430/wje.v9n2p123

Dabir, A. R., \& Azarpira, M. (2017). Organizational commitment and its impact on employees' individual interactions. International Journal of Human Capital in Urban Management, 2(1), 49-56. https://doi.org/10.22034/ijhcum.2017.02.01.005

Emhan, A., Arslan, V., Yaşar, M. F., \& Çocuk, S. (2018). Relationship between Organizational Commitment, Job Satisfaction, Emotional Regulation and Mediating Effect of Political Perceptions: An Application in the Education Sector. European Journal of Educational \& Social Sciences, 3(2), 250-270.

Govender, L. \& Grobler, S., (2017). Job Satisfaction and Organizational Commitment in a South African Airline, African Journal of Hospitality. Tourism and Leisure, 6(2), 1-24.

Inanc, E. E., \& Ozdilek, E. (2015). Relationship between the organizational commitment and job satisfaction of academic staff in Turkey. International Organization for Research and Development, 12.

Judge, T. A., Bono, J. E., \& Locke, E. A. (2000). Personality and job satisfaction: The mediating role of job characteristics. Journal of applied psychology, 85(2), 237. https://doi.org/10.1037/0021-9010.85.2.237

Parvin, M. M., \& Kabir, M. N. (2011). Factors affecting employee job satisfaction of pharmaceutical sector. Australian journal of business and management research, 1(9), 113.

Kathawala, Y., Kevin, M., \& Dean, E. (1990). Preference between Salary or JS Increase. International Journal of Manpower, 11(7), 711-722. https://doi.org/10.1108/01437729010004174

Kaur, K., \& Sandhu, H. S. (2010). Career stage effect on organizational commitment: Empirical evidence from Indian banking industry. International Journal of Business and Management, 5(12), 141. https://doi.org/10.5539/ijbm.v5n12p141 
Lizote, S. A., Verdinelli, M. A., \& do Nascimento, S. (2017). Organizational commitment and job satisfaction: a study with municipal civil servants. RAP: Revista Brasileira De Administração Pública, 51(6). https://doi.org/10.1590/0034-7612156382

Lumley, E. J., Coetzee, M., Tladinyane, R., \& Ferreira, N. (2011). Exploring the job satisfaction and organisational commitment of employees in the information technology environment. Southern African Business Review, $15(1)$.

Malik, M. E., Nawab, S., Naeem, B., \& Danish, R. Q. (2010). Job satisfaction and organizational commitment of university teachers in public sector of Pakistan. International journal of business and management, 5(6), 17. https://doi.org/10.5539/ijbm.v5n6p17

Manap, R. (2017). Job Satisfaction and Organizational Commitment among Employees, Proceeding of the 4th International Conference on Management and Muamalah, (ICoMM 2017), pp. 539-547.

Macdonald, S., \& Maclntyre, P. (1997). The generic job satisfaction scale: Scale development and its correlates. Employee Assistance Quarterly, 13(2), 1-16. https://doi.org/10.1300/J022v13n02_01

Meyer, J. P., \& Allen, N. J. (1991). A three-component conceptualization of organizational commitment. Human resource management review, 1(1), 61-89. https://doi.org/10.1016/1053-4822(91)90011-Z

Meyer, J. P., \& Herscovitch, L. (2001). Commitment in the workplace: Toward a general model. Human resource management review, 11(3), 299-326.

Malhotra, N., \& Mukherjee, A. (2004). The relative influence of organisational commitment and job satisfaction on service quality of customer-contact employees in banking call centres. Journal of services Marketing. https://doi.org/10.1108/08876040410536477

Nacpil, L. E., \& Lacap, J. P. G. (2018). Job Satisfaction and Organizational Commitment: The Case of Employees of a Government Agency in Region III, Philippines. PREO Journal of Business and Management, Vol. 1, No. 1, pp. $1-15$.

Nguyen, T. N., Mai, K. N., \& Nguyen, P. V. (2014). Factors Affecting Employees' Organizational Commitment-A Study of Banking Staff in Ho Chi Minh City, Vietnam. Journal of Advanced Management Science Vol, 2(1), 7-11. https://doi.org/10.12720/joams.2.1.7-11

Pandey, C., \& Khare, R. (2012). Impact of job satisfaction and organizational commitment on employee loyalty. International Journal of Social Science \& Interdisciplinary Research, 1(8), 26-41.

Pham, H. (2017). Determinants of Job Satisfaction and Organizational Commitment of Employees within the Telecommuting Environment in Vietnam. International Journal of Scientific \& Engineering Research, Vol.7, No.11, pp. 1511-1520. https://doi.org/10.2139/ssrn.2986311

Porter, L. W., Steers, R. M., Mowday, R. T., \& Boulian, P. V. (1974). Organizational commitment, job satisfaction, and turnover among psychiatric technicians. Journal of applied psychology, 59(5), 603. https://doi.org/10.1037/h0037335

Saari, L. M., \& Judge, T. A. (2004). Employee attitudes and job satisfaction. Human Resource Management: Published in Cooperation with the School of Business Administration, The University of Michigan and in alliance with the Society of Human Resources Management, 43(4), 395-407. https://doi.org/10.1002/hrm.20032

Spector, P. (2008). Industrial and Organizational Behavior (5th ed.). John Wily \& Sons, USA.

Spector, P. E. (1997). Job satisfaction: Application, assessment, causes, and consequences (Vol. 3). Sage publications. https://doi.org/10.4135/9781452231549

Yılmaz, E., Özer, G., \& Günlük, M. (2014). Do organizational politics and organizational commitment affect budgetary slack creation in public organizations. Procedia-Social and Behavioral Sciences, 150, 241-250. https://doi.org/10.1016/j.sbspro.2014.09.047 